\title{
Analysis of Trade Complementarity and Competitiveness between China and Countries under "the Belt and Road" Initiative
}

\author{
Peizhi Wang ${ }^{1, \mathrm{a},}$ Lingxi $\mathrm{Chu}^{2, \mathrm{~b},{ }^{*}}$ and Binbin $\mathrm{Guo}^{3, \mathrm{c}}$ \\ ${ }^{1}$ Shandong University of Finance and Economics, Jinan, China \\ ${ }^{2}$ Shandong University of Finance and Economics, Jinan, China \\ ${ }^{3}$ Shandong University of Finance and Economics, Jinan, China \\ a wpzmail@126.com, bclx0459@163.com, ${ }^{c 920016576 @ q q . c o m ~}$
}

\begin{abstract}
With the process of reform and opening up and global economic integration, foreign direct investment has gradually emerged and developed in China, and has gradually occupied a more and more important position in the economic development of our country. Overseas companies and outward direct investment have become an important factor to promote Shandong's economic development. By analyzing the current situation of Shandong's foreign direct investment, this paper provides relevant reference and guidance for Shandong's economic development.
\end{abstract}

Keywords-Shandong Province; Foreign direct investment; Economic development

\section{INTRODUCTION}

Outward Foreign direct investment (OFDI) refers to the economic behavior of an investor to export the intangible assets, such as capital, equipment, technology and management skills, to obtain effective control over the management of foreign enterprises. Under the background of economic globalization, foreign direct investment has become the main feature of today's world economic activities. In recent years, the international market of some traditional processing industries in China has been saturated. The Asian financial crisis has greatly reduced the growth rate of China's exports. Enterprises' foreign investment can not only avoid the tariff and non-tariff barriers that some countries have set on Chinese products, lead to the export of domestic raw materials, auxiliary materials, semi-finished products and complete sets of equipment, but also provide an accurate international market market for domestic enterprises, and reduce the blindness in the export. It is of realistic and long-term significance to actively carry out foreign direct investment for Shandong enterprises to "go out" and enhance their international competitiveness.

\section{AN ANALYSIS OF THE NECESSITY OF FOREIGN DIRECT INVESTMENT IN SHANDONG}

According to the statistics of the Ministry of Commerce in China, in the past 16 years, there have been 599 newly approved overseas investment enterprises (Institutions) in Shandong Province, and China has invested 26 billion 540 million dollars (about 176 billion 260 million yuan), up about $70.2 \%$, and 527 of the real investment enterprises were realized in the year, and the cumulative realization of the total foreign direct investment was 12 billion 980 million dollars(about 86 billion 230 million yuan), an increase of 1.4 times. Thus, foreign direct investment plays an increasingly important role in the economic development of Shandong province.

\section{A. Theoretical analysis of the necessity of Shandong's foreign direct investment}

\section{1) Monopoly advantage theory}

$\mathrm{Mr}$ hammer believes that the motivation of TNCs to invest in foreign direct investment stems from the market defect, namely, the incompleteness of the market. Because of incomplete competition, TNCs have a series of monopoly advantages, such as economies of scale, monopoly of production, advantages of information and network, advantages of marketing channels and international popularity.

The theory of monopoly advantage emphasizes the possibility of earning profits from foreign direct investment. We can also see from this theory that enterprises with monopolistic advantages must set up transnational corporations for outward direct investment. Only through this way can the local enterprises in the host country get rid of their inferior position, so as to get the local government policy support, familiar with the host country's investment environment and the local market, reduce the transportation cost and so on, so as to increase their own benefits. 


\section{2) Eclectic theory of international production}

Denning summed up the traditional theory that the enterprise foreign direct investment can make use of ownership advantage, internal advantage and location advantage. Only when the enterprise has these three advantages, it has the condition of foreign direct investment.

The theory of international production compromise further believes that the combination of ownership advantage, location advantage and internal advantage can not only explain whether international enterprises or transnational corporations have the advantage of direct investment, but also help enterprises to choose the way of international marketing and the way to establish advantages. The next table is the option proposed by Professor Denning.

TABLE I The Exhibition of EClectic Theory of INTERNATIONAL Production

\begin{tabular}{|c|c|c|c|}
\hline mode & Ownership advantage & $\begin{array}{c}\text { Internalization } \\
\text { advantage }\end{array}$ & $\begin{array}{c}\text { Location } \\
\text { advantage }\end{array}$ \\
\hline $\begin{array}{c}\text { Foreign direct investment } \\
\text { (investment) }\end{array}$ & yes & yes \\
\hline Export (trade) & yes & yes & no \\
\hline Transfer of intangible assets & yes & no & no \\
\hline
\end{tabular}

B. On-site analysis of the necessity of foreign direct investment of Shandong Enterprises

1) It is a necessary choice to relieve the pressure of resources in our province

As far as energy is concerned, Shandong, as a major province of energy output, is not short of energy. But because of the low quality energy and the large amount of coal fired in thermal power, the real consumption situation in Shandong province is the shortage of raw coal, the large outer tune of the finished oil, and the increase of the net input of the raw coal year by year. From the point of view of land resources, the land area of Shandong province is large, but the population is large, and the contradiction between people and land is very prominent. From the perspective of mineral resources, Shandong is rich in mineral resources, especially in energy, building materials, chemical raw materials, gold, iron and other resources. Because the total population of Shandong is large, the amount of per capita resources is very limited. These are the factors that can not be ignored in limiting economic development. Through foreign direct investment, enterprises make investment and set up factories to transform demand into international market, which can directly obtain resources from the host country, and ensure the supply of raw materials and a stable and stable supply.

2) It is inevitable choice to deal with increasingly intensified trade protectionism and various trade barriers

Since its accession to the WTO, China has further opened up its domestic market and promoted the integration of domestic market and international market. In 2013, it has become the world's largest cargo trading country. In 2016, the total import and export volume of our country still amounted to 243344 billion yuan. But at the same time, trade friction has become an important issue between our country and our trading partners. China's export products are facing various trade remedy measures and trade barriers in the importing countries, and China's export products are subject to various entry restrictions. China has been the largest country in the world for 21 years, and has been the largest country in the world for 10 years. These anti-dumping investigations involve more than 45 kinds of commodities, such as five mines, chemical industry, textile, mechanical and electrical, agricultural products and so on. Statistics show that in the first half of 2016, China's export products encountered 65 cases of trade relief investigation launched from 17 countries (regions), up $66.67 \%$, and the amount involved in the case was 8 billion 544 million dollars, up $156 \%$. Compared with the same period in 2015, there were only 37 cases involving 3 billion 500 million dollars. In only half a year, 65 cases of trade remedy investigations exceeded the total amount of 2015.

In the face of such fierce competition in the international market, in order to seek a place, reduce trade frictions and maintain their competitiveness, enterprises in our province need to invest directly in foreign countries, establish factories directly abroad, avoid various trade barriers and import restrictions on the host country, and maintain the existing export market share. Occupying host country's market share, selling products and increasing profits, it can also concentrate on using various resources to promote the upgrading of domestic industries. 
III. CONCRETE ANALYSIS OF THE FEASIBILITY OF FOREIGN DIRECT INVESTMENT OF SHANDONG'S ENTERPRISES
A. Shandong's overall economic strength is enhanced and its foreign direct investment capability is enhanced.

TABLE II The GDP Situation In China AND Shandong Province OVER THE Years

\begin{tabular}{|c|c|c|c|c|}
\hline & China GDP & ShanDong GDP & Per capita in China & Per capita GDP in ShanDong \\
\hline 2000 & 1211346869605 & 8337 & 6713 & 9325 \\
\hline 2001 & 1339395718865 & 9195 & 7371 & 10195 \\
\hline 2002 & 1470550015081 & 10275 & 8036 & 11339 \\
\hline 2003 & 1660287965662 & 12078 & 9016 & 13267 \\
\hline 2004 & 1955347004963 & 15021 & 10556 & 16412 \\
\hline 2005 & 2285965892360 & 18366 & 12271 & 20096 \\
\hline 2006 & 2752131773355 & 21900 & 14693 & 23546 \\
\hline 2007 & 3552182311652 & 25776 & 18865 & 32936 \\
\hline 2008 & 4598206091384 & 30933 & 24297 & 45894 \\
\hline 2009 & 5109953609257 & 33896 & 26866 & 47335 \\
\hline 2010 & 61006204888667 & 39169 & 31920 & 51767 \\
\hline 2011 & 7572553836875 & 45361 & 33798 & 56884 \\
\hline 2012 & 8560547314679 & 50013 & 38022 & 60879 \\
\hline 2013 & 9607224481532 & 55230 & 42462 & 64168 \\
\hline 2014 & 10482372109961 & 59426 & 46098 & 67706 \\
\hline 2015 & 11064666282625 & 45712 & 48414 & 48738 \\
\hline 2016 & 11199145157649 & 67008 & & \\
\hline
\end{tabular}

The gross national product of Shandong province increased from 833 billion 747 million yuan in 2000 to 6 trillion and 700 billion 819 million yuan in 2016, from the total GDP in the country from $8.8 \%$ to $9.19 \%$. Our province has a relatively strong industrial base and a perfect industrial system, the industrial sector is complete, and in all industries, there are enterprises of different sizes and different levels of technology.

With the implementation of the "one and two wings" development strategy, the "one", composed of the peninsula urban group and the economic circle of the provincial capital city group, achieved 1 trillion and 860 billion 140 million yuan at the end of 2015 , accounting for $71.9 \%$ of the whole province, up $16 \%$ over the previous year. The Yellow River delta efficient eco economic zone achieved a gross domestic product of 382 billion 640 million yuan, an increase of $16.6 \%$. The South Shandong Economic Belt achieved a GDP of 561 billion 290 million yuan, an increase of $16.4 \%$. With the implementation of the "double 30 project", the economic strength of the county has been further strengthened, and the average increase of the county level fiscal revenue reached $28.2 \%$, and the local fiscal revenue of 37 counties (cities and districts) exceeded 1 billion yuan. The overall economic strength of Shandong province has been continuously enhanced, and it has the most basic capital advantage of foreign direct investment.
B. The experience advantage of the accumulation of foreign investment in Shandong

Shandong's foreign direct investment started in 1980s, and accumulated valuable development experience and lessons through the development of more than 20 years. In the process of development, a large number of large and powerful enterprise groups have been formed, such as Haier group, Weichai Holding Group Co., Ltd., Nanshan Group Co., Ltd. and so on.

Take Weichai holdings as an example: in 2008, the saturation and space of the domestic heavy truck market were restricted. Weichai Power began to seek overseas mergers and acquisitions, and dispersed the way of business. In 2009, the company acquired the French baudouin company, further expanding the whole series of engine business layout. In August 2012, weichai acquired $25 \%$ of kaiao company and $70 \%$ of linde hydraulics with 738 million euros, and gradually increased its shareholding to $43.26 \%$, which was realized in 2014.Overseas revenue accounted for 47 percent of weichai's total revenue in 2016, and kaiao contributed 650 million yuan to its parent's net profit after the acquisition, accounting for nearly 27 percent of the parent's net profit, weichai officials told reporters. Compared to relatively weak domestic economic conditions, foreign acquisitions rather achieved good results, the overseas layout not only improved the company's financial 
statements, more important is through mergers and acquisitions got the core technology. These experiences are of great significance for supporting and encouraging other enterprises in our province to go out and make foreign direct investment.

\section{ANALYSIS ON THE SCALE AND CHARACTERISTICS OF OFDI IN SHANDONG PROVINCE}

\section{A. Analysis on the scale of OFDI in shandong province}

In recent years, the pace of China's regional economic integration is getting faster and faster. With the implementation of "The Belt and Road" strategy, the foreign direct investment of Shandong enterprises is facing a rare opportunity for development. In the year of the 13th Five-Year plan, 2016, the total amount of foreign investment in the country was 170 billion 130 million 900 thousand US dollars, and the foreign direct investment in Shandong remained steady and fast growth, the number of foreign investment projects reached 599, the total foreign investment amounted to 26 billion 536 million US dollars, accounting for about $15.6 \%$ of the total foreign investment in the country, and Shandong province. The scale of foreign direct investment of enterprises has been firmly in the forefront of the whole country. The following table shows Shandong's foreign direct investment and its share in the whole country.

TABLE III The SituATION OF ForeIGN INVESTMENT IN SHANDONG

\begin{tabular}{|c|c|c|c|}
\hline Year & Number of items & Investment amount/Billion of dollars & Account for the proportion of the country \\
\hline 2012 & 361 & 44.33 & $5.10 \%$ \\
\hline 2013 & 443 & 45.12 & $4.20 \%$ \\
\hline 2014 & 524 & 62.89 & $5.10 \%$ \\
\hline 2015 & 589 & 155.95 & $10.70 \%$ \\
\hline 2016 & 599 & 265.36 & $15.60 \%$ \\
\hline
\end{tabular}

B. Analysis on the characteristics of OFDI in shandong province

1) The trend of diversification in investment region is obvious

By 2015, Shandong's foreign direct investment has covered more than 140 countries and regions of six continents, of which Asia accounts for about $43.3 \%$, Africa's investment ratio is about $6.1 \%$, Europe accounts for about $8.3 \%$, Latin America accounts for $7.9 \%$, Oceania accounts for $12.5 \%$, and North America (no Bermuda) accounts for the ratio. It's about $22 \%$. It can be seen that the region of Shandong province's outward direct investment has shown obvious diversification development trend.

In the top ten countries (regions) of Shandong's foreign direct investment, more than $50 \%$ of the investment is concentrated in countries and regions with abundant capital and advanced service industry in Hongkong, the United States and Singapore. The investment of Hongkong has always occupied a large proportion, from 174864 billion US dollars in 2014 to 199144 billion in 2015. The US dollar and a considerable proportion of OFDI are distributed in Southeast Asian countries with similar geographically rich labor in Indonesia, Kampuchea and Thailand.

TABLE IV THE DistRIBUTION OF FoREIGN INVESTMENT IN SHANDONG

\begin{tabular}{|c|c|c|c|c|}
\hline \multirow{2}{*}{ Ranking } & \multicolumn{2}{|c|}{2014} & \multicolumn{2}{c|}{2015} \\
\cline { 2 - 5 } & Country & Amount/Billions of dollars & Country & Amount/Billions of dollars \\
\hline 1 & HongKong & 174864 & American & 199144 \\
\hline 2 & American & 63846 & HongKong & 179099 \\
\hline 3 & Australia & 39464 & Australia & 168525 \\
\hline 4 & Indonesia & 32676 & Canada & 126000 \\
\hline 5 & Cambodia & 23417 & Singapore & 89532 \\
\hline 6 & Malaysia & 20959 & Peru & 77841 \\
\hline 7 & Russia & 20859 & Indonesia & 62035 \\
\hline 8 & Singapore & 19973 & Vietnam & 61840 \\
\hline 9 & Pakistan & 16395 & Germany & 54586 \\
\hline 10 & Thailand & 16098 & Cambodia & 54445 \\
\hline
\end{tabular}


As shown in the picture:

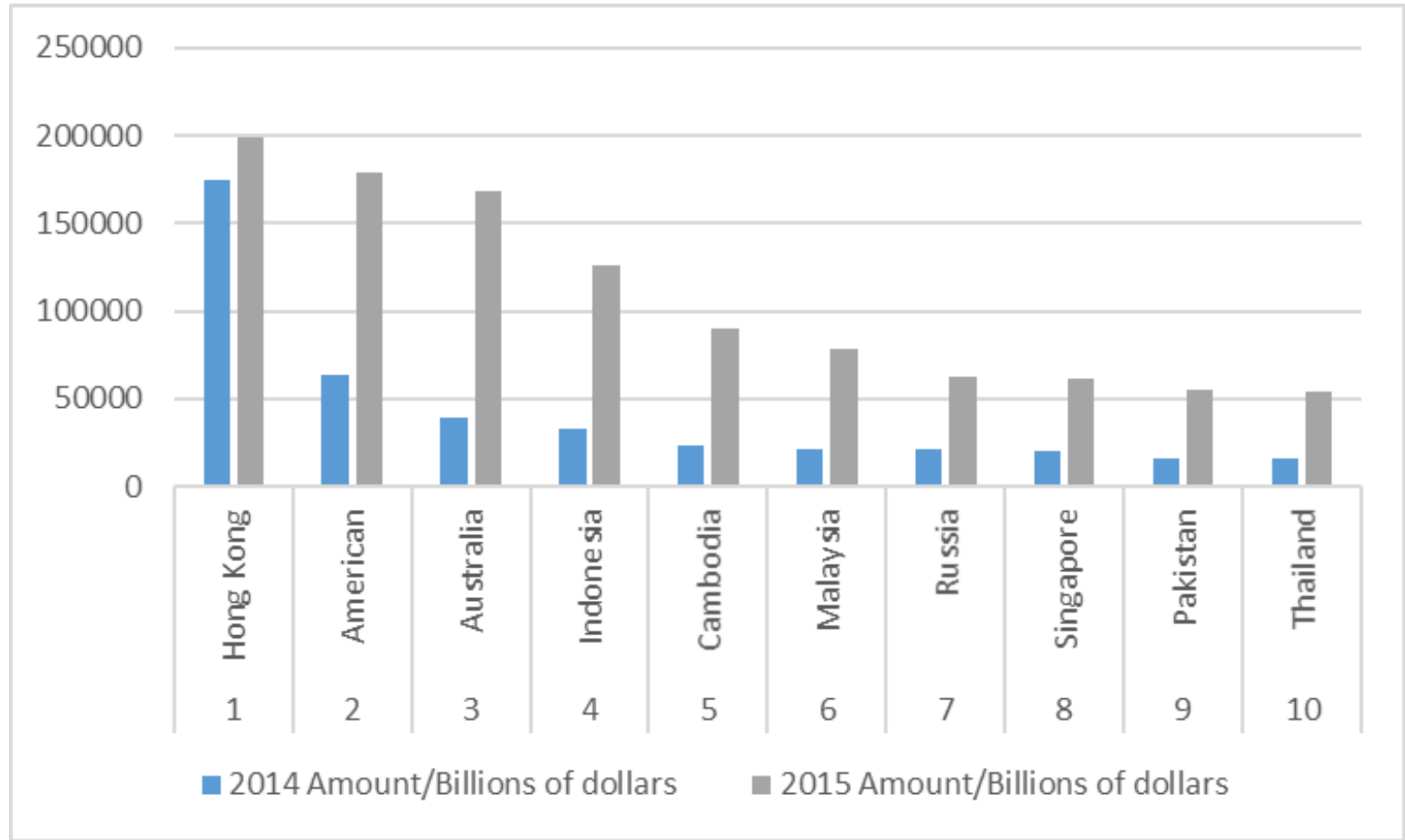

Fig. 1 The Distribution of Foreign Investment in Shandong

2) The structure of foreign investment industry is more perfect

TABLE V ANALYSIS OF OVERSEAS INVESTMENT ACTIVITIES

\begin{tabular}{|c|c|c|c|c|c|c|c|c|}
\hline \multirow{2}{*}{ Category } & \multicolumn{70}{c|}{ Overseas investment activities } \\
\cline { 2 - 10 } & 2013 & 2014 & 2015 & Accumulative & 2013 & 2014 & 2015 & Accumulative \\
\hline Total & 443 & 524 & 589 & 4675 & 556082 & 628873 & 1559474 & 3830585 \\
\hline $\begin{array}{c}\text { Trade } \\
\text { enterprise }\end{array}$ & 181 & 226 & 227 & 1964 & 100671 & 139035 & 152322.2 & 562207 \\
\hline $\begin{array}{c}\text { Nontrade } \\
\text { enterprise }\end{array}$ & 234 & 257 & 332 & 2166 & 455410 & 489838 & 1407152 & 3268378 \\
\hline $\begin{array}{c}\text { Resourse } \\
\text { development } \\
\text { enterprise }\end{array}$ & 58 & 31 & 61 & 418 & 113871 & 136281 & 342672.5 & 935419 \\
\hline
\end{tabular}




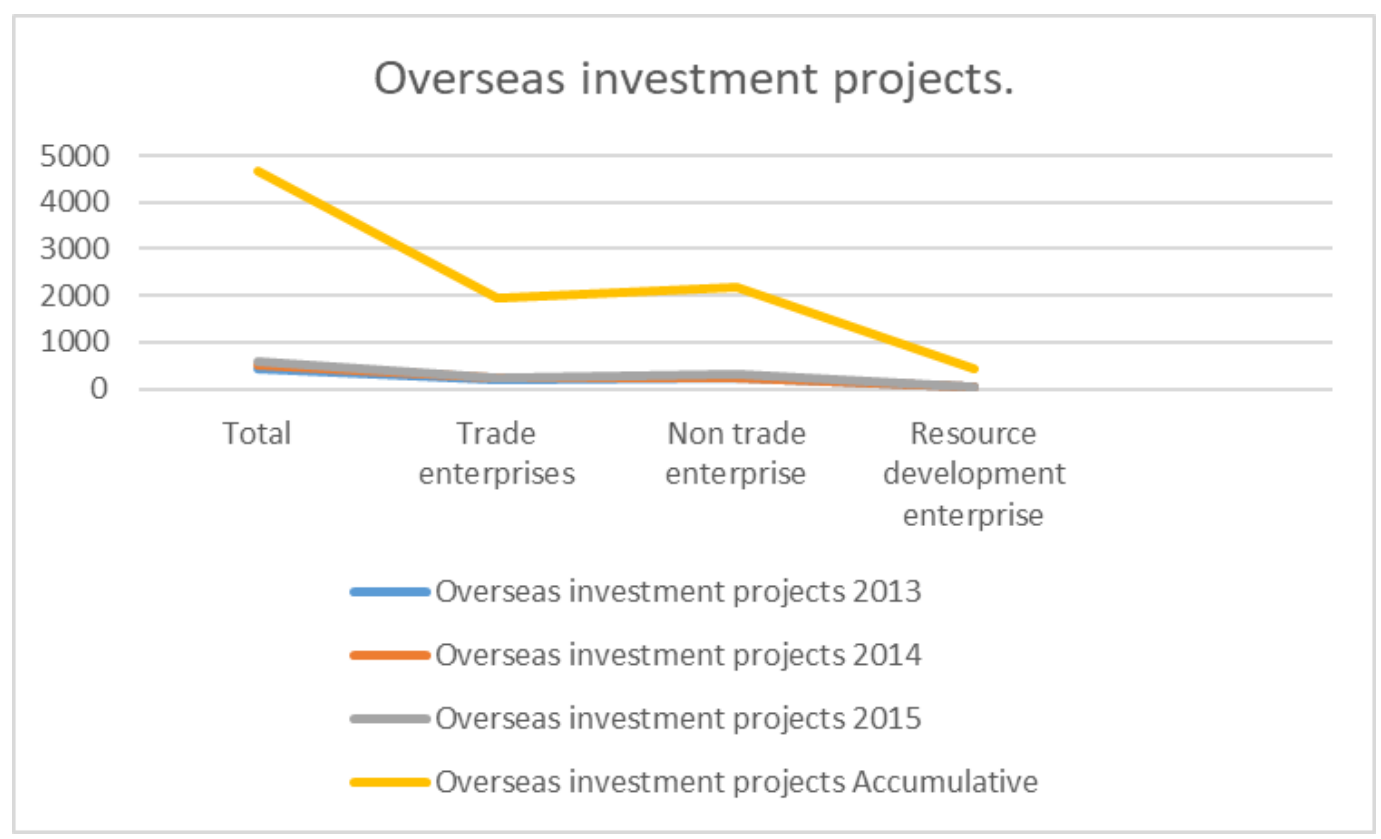

Fig. 2 Overseas Investment Project

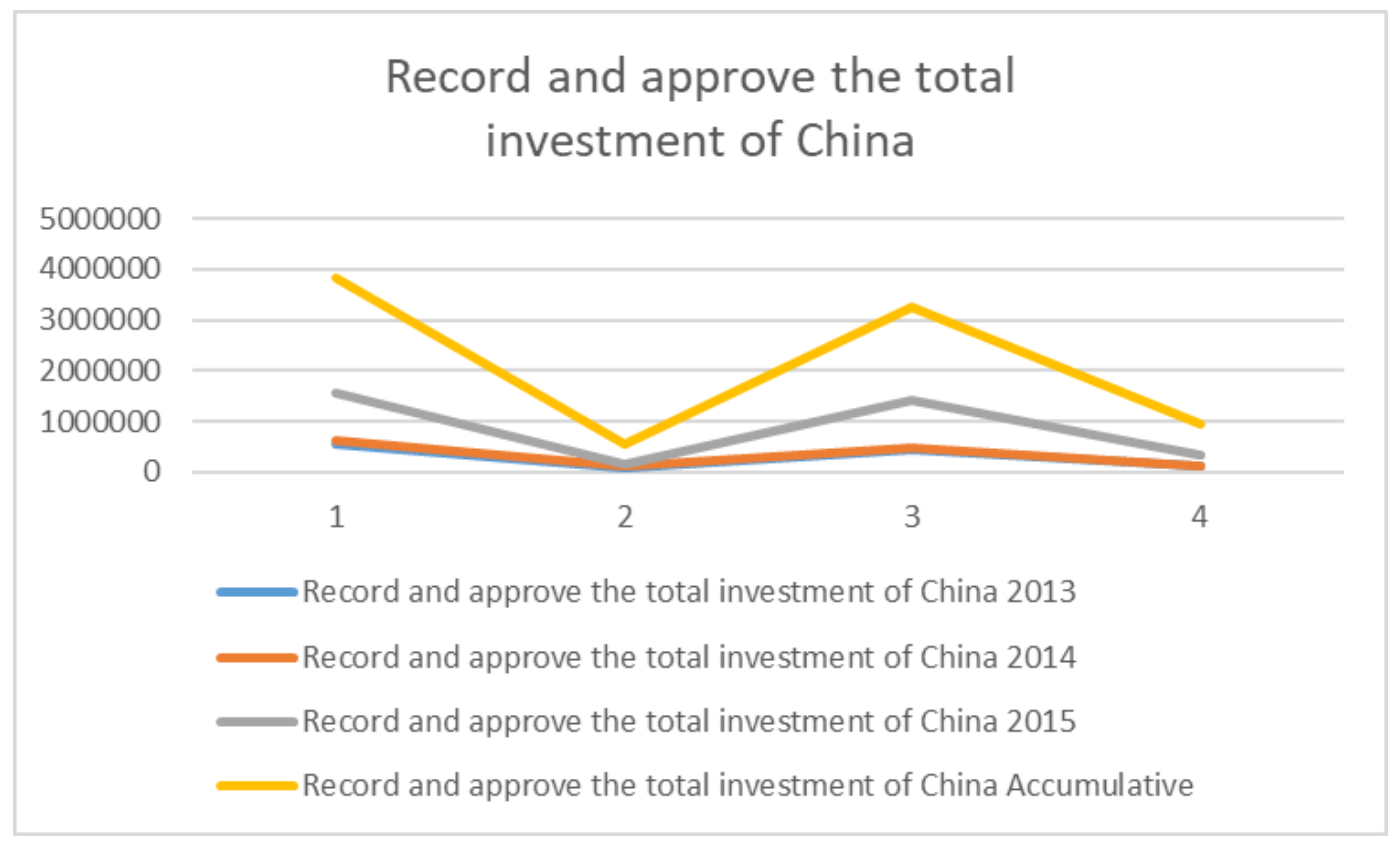

Fig. 3 Record and Approve the Total Investment of China

In the past, China's foreign investment tends to be dominated by natural resources. With the development of the economy, the proportion of foreign investment in market seeking and technology seeking is increasing gradually. Both the food processing industry, the household electrical appliance industry, the textile industry, the clothing industry, the machinery industry, the pharmaceutical industry, the transportation industry, and so on are all involved in the foreign direct investment of our province. Our province's outward foreign direct investment industry has gradually expanded from the three major industries to other sectors of agriculture, fisheries, technology services, medicine, tourism and other services. Among them, resource development, processing and manufacturing and service trade have gradually become the three pillar areas of our province's foreign investment.

3) The way of investment is more flexible

As China's foreign investment continues to mature and develop, investment methods are more flexible. Mergers, acquisitions, cross share swap and other investment methods are widely adopted. In recent years, cross-border mergers and acquisitions have become the main way of Chinese enterprises' OFDI. In 1988, China's foreign investment through crossborder mergers and acquisitions reached 16 million 500 
thousand dollars, accounting for only $1.94 \%$ of China's total foreign direct investment. Since 1990s, cross-border mergers and acquisitions have been growing steadily. Apart from 1999, the share of cross-border mergers and acquisitions has maintained an annual growth rate of over $10 \%$. After 2001, the proportion of transnational mergers and acquisitions remained at about $50 \%$, and there was a large fluctuation in individual years, indicating that the investment mode of Chinese enterprises to adopt transnational mergers and acquisitions has not yet matured. But it can not be denied that cross-border mergers and acquisitions have become an important way for Chinese enterprises to invest in foreign direct investment.

Take Haier group, an excellent enterprise in our province as an example, Haier's internationalization strategy can be summarized as the "three- three" strategy. The "three-three" strategy, including quality, science and technology and market, should be internationalized in three aspects. In fact, the internationalization strategy continues to be a brand strategy. According to this idea, it is an international approach to "difficult and easy" to focus on the market of developed countries. Haier is intended to create a brand in developed countries in order to create a brand potential energy that will turn into a kinetic energy when Haier expands to developing countries, making it easier for developing countries to accept Haier's brand; and the international image of Haier will promote Haier to develop at home.

\section{CONCLUSION}

Shandong's foreign direct investment has played a huge role in the development of Shandong's economy, but there are also many problems. In order to further adapt to the development of the new situation, especially the spread of the financial crisis, Shandong provincial government and enterprises should actively cooperate to overcome their own shortcomings and take the initiative to cope with the crisis. Under the premise of macro regulation, the government should encourage qualified enterprises to absorb foreign high-end talents through transnational mergers and acquisitions, expand the introduction of advanced technology and develop foreign market space. On the one hand, enterprises can achieve the rapid development of their economic benefits, and on the other hand, contribute to the early release of crises in Europe and the United States.

\section{REFERENCES}

[1] Zhang Henglong, Zhou Yuancheng.Journal of Xinjiang Normal University, 2015,36 (4): 76-84.

[2] He Min, Zhang Ningning, Huang Zequn.Competitive and Complementary Analysis of China's Agricultural Products Trade along the Belt and Road [J]. Agricultural Economics, 2016 (11)

[3] Lv Hongfen, Yu Y. Study on the Competitiveness and Complementarity of China-Brazil Bilateral Trade [J] .International Trade Issues, 2011 (02).

[4] Rui Yuan, An Empirical Study on the Export Potential of China's EU Trade in Goods, D. Shandong University, 2016.

[5] Yun ZHENG, Comparative Advantage in China-EU Trade and Status of International Division of Labor, J. International Commerce. 05(2006) 913.

[6] Zhang Henglong, Zhou Yuancheng.Journal of Xinjiang Normal University, 2015,36 (4): 76-84.

[7] He Min, Zhang Ningning, Huang Zequn.Competitive and Complementary Analysis of China's Agricultural Products Trade along the Belt and Road [J]. Agricultural Economics, 2016 (11)

[8] Lv Hongfen, Yu Y. Study on the Competitiveness and Complementarity of China-Brazil Bilateral Trade [J] .International Trade Issues, 2011 (02).

[9] Rui Yuan, An Empirical Study on the Export Potential of China's EU Trade in Goods, D. Shandong University, 2016.

[10] Yun ZHENG, Comparative Advantage in China-EU Trade and Status of International Division of Labor, J. International Commerce. 05(2006) 913. 